p-ISSN. 2086-9029

e-ISSN. 2654-5675

Vol. 22 No. 1, Hlm. 1-158, Juni 2020

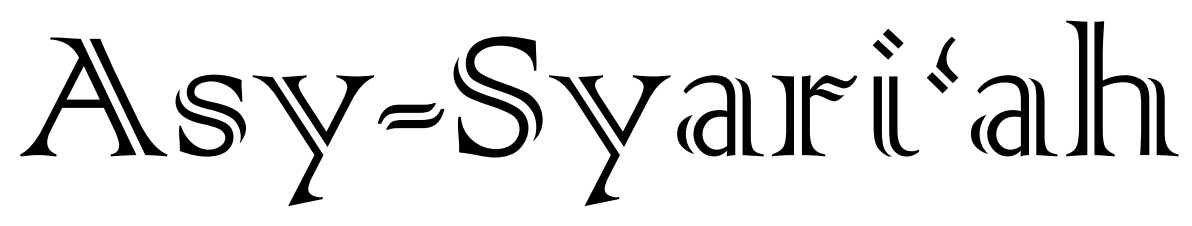

- Hukum Waris Islam Sebagai Instrumen Kepemilikan Harta

$(1-20)$ Hafidz Taqiyyudin

- Komparasi Metodologi Hukum Aliran Maqasidi dan Aliran Syakli

$(21-34)$ Hudzaifah Achmad Qotadah

- Reinterpretasi Hak Ijbar dalam Hukum Perkawinan Islam di Keluarga $(35-50)$ Pesantren

Kudrat Abdillah

- Dimensi Kondisionalitas dan Fleksibilitas Al-Quran bagi Implementasi $(51-66)$ Fatwa DSN-MUI tentang Produk Bank Syariah

Ahmad Hasan Ridwan, Asep Rahmat

- Validitas Hadis Tidak Ada Kisas bagi Orang Tua yang Membunuh Anaknya

Moh. Ahsanuddin Jauhari, Enceng Arif Faizal, Syahrul Anwar, Atep Mastur, Deden Najmudin

- Penguatan Resolusi Konflik Berbasis Tradisi Sunnah Nabi

Alamsyah

- Sistem Perencanaan, Pelaksanaan dan Pengawasan Industri Halal di Wilayah Provinsi Banten

Akhyakudin, Suja'i, Muhammad Abduh

- Reformulation of Family Legal in Indonesia for Female Maslahah

Wahidullah, Murniati, Yushinta Eka Farida, Jumaiyah

- The Concept and Aplication of Covenant in Financing Gold Pawn By Sharia Bank in West Java

Neni Nuraeni, Dewi Sulastri, Zulbaidah

- Tinjauan Sosiologi Hukum tentang Kepatuhan Masyarakat terhadap ( $147-158)$ Undang-Undang Wakaf

Deden Effendi

FACULTY OF SHARIA AND LAW

STATE ISLAMIC UNIVERSITY SUNAN GUNUNG DJATI BANDUNG-INDONESIA IN COLLABORATION WITH ASOSIASI SARJANA SYARIAH INDONESIA 


\section{Asy-Syari'ah}

Volume 22, Number 1, 2020

\section{EDITOR-IN-CHIEF}

Ine Fauzia

\section{EDITORIAL BOARD}

Sofyan al-Hakim, UIN Sunan Gunung Djati Bandung, Indonesia Deni Kamaludin Yusup, UIN Sunan Gunung Djati Bandung, Indonesia Meria Utama, Fakultas Hukum Univrsitas Sriwijaya, Indonesia Dewi Mayaningsih, UIN Sunan Gunung Djati Bandung, Indonesia Andrey Sujatmiko, Fakultas Hukum Universitas Trisakti, Jakarta, Indonesia Hetty Hassanah, Universitas Komputer Indonesia, Indonesia

\section{PEER-REVIEWERS}

Muhammad Irfan Helmy, IAIN Salatiga, Semarang, Indonesia Ahmad Ali Nurdin, UIN Sunan Gunung Djati Bandung Tajul Arifin, UIN Sunan Gunun Djati Bandung, Indonesia Mohamad Anton Athoillah, UIN Sunan Gunung Djati Bandung, Indonesia Mrs. Renny Supriyatni, Universitas Padjadjaran, Indonesia Ahmad Tholabi Karlie, UIN Syarif Hidayatullah Jakarta, Indonesia Ija Suntana, UIN Sunan Gunung Djati Bandung, Indonesia Zezen Zaenal Mutaqin, University of California, Los Angeles, United States Ahmad Fathonih, UIN Sunan Gunung Djati Bandung, Indonesia Rahman Syamsuddin, Universitas Islam Negeri Alauddin Makassar, Indonesia

\section{PROOFREADER/DESIGN COVER}

Nanang Sungkawa

\section{LAYOUT EDITOR}

Opik Rozikin

Asy-Syari' ah has been accredited based on the determination of Director General of Research and Development Strengthening, Ministry of Research, Technology and Higher Education of Republic of Indonesia, No. 14/E/KPT/2019 (valid until 2023). 


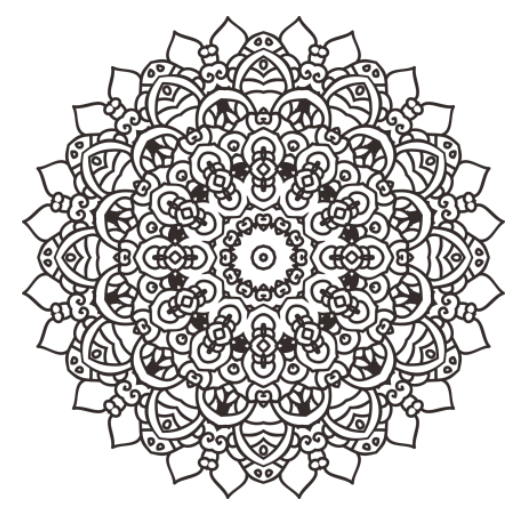

\title{
SISTEM PERENCANAAN, PELAKSANAAN DAN PENGAWASAN INDUSTRI HALAL DI WILAYAH PROVINSI BANTEN
}

\author{
${ }^{1}$ Ahyakudin, ${ }^{2}$ Suja'i, ${ }^{3}$ Muhammad Abduh \\ ${ }^{123}$ Universitas Sultan Ageng Tirtayasa \\ E-mail: ahyakudin_200o@yahoo.com, sujai.saleh1@gmail.com, \\ muhammad.abduh@untirta.ac.id
}

\begin{abstract}
The role of the industrial sector in meeting the livelihoods of the people of Banten should be accompanied by efforts to develop an industrial system that prioritizes the halal value on its production. The development of the halal industry can be realized with a system of planning, implementation and supervision in accordance with the principle of halal thayyibah. The method that will be used in this research is descriptive qualitative. Information gathered from the initial research is expected to provide an overview and prescription of the relationship between the planning, implementation, and supervision of the implementation of the Halal Industry in Banten Province. The results of this study explain that aspects of industrial planning should pay attention to aspects of Maqashid Syariah and aspects of trust as an effort to provide certainty that industrial products are in accordance with halal provisions. In practice, industrial management should not only issue technical rules but must also be accompanied by qualifications of basic sharia knowledge in production activities. While in the aspect of supervision, the person in charge must have a deep understanding of the aspects of $\mathrm{li}$ dzatihi, li ghairihi, and li aqibatihi as the main components of the halal system. Constraints on halal industry development are experienced by micro and small businesses due to certification costs, inadequate halal industry governance, and fears of leakage of company product secrets.
\end{abstract}


Keywords: halal industry, planning, implementation, supervision, sharia

\begin{abstract}
Abstrak: Peran sektor industri dalam memenuhi hajat hidup masyarakat Banten hendaknya harus dibarengi upaya pengembangan sistem Industri yang mengedepankan nilai halal pada produksinya. Pengembangan Industri halal dapat diwujudkan dengan sistem perencanaan, pelaksanaan dan pengawasan yang sesuai dengan prinsip halâlan thayyibah. Metode yang akan digunakan dalam penelitian ini ialah deskriptif kualitatif, Informasi yang tergali dari penelitian awal diharapkan dapat memberikan gambaran dan preskripsi hubungan antara sistem perencanaan, pelaksanaan, dan pengawasan terhadap penyelenggaraan Industri Halal di Provinsi Banten. Hasil penelitian ini menjelaskan bahwa aspek perencanaan industri hendaknya memperhatikan aspek maqashid Syariah dan aspek amanah sebagai upaya memberikan kepastian bahwa produk industri telah sesuai dengan ketentuan halal. Dalam pelaksanaannya, manajemen industri hendaknya tidak hanya mengeluarkan aturan-aturan tekhnis semata namun juga harus dibarengi dengan kualifikasi pengetahuan kesyariahan mendasar pada kegiatan produksi. Sedangkan dalam aspek pengawasan, penanggungjawab harus memiliki pemahaman mendalam pada aspek li dzatihi, li ghairihi, dan li aqibatihi sebagai komponen utama sistem halal. Kendala pengembangan Industri halal dialami oleh usaha mikro dan kecil dikarenakan biaya sertifikasi, tata kelola industri halal belum memadai, serta ketakutan akan bocornya rahasia produk perusahaan.
\end{abstract}

Kata-kata Kunci: industri halal, perencanaan, pelaksanaan, pengawasan, syariah 
Ahyakudin, Suja'i, M. Abduh, Sistem Perancangan, Pelaksanaan dan Pengawasan Industri... | 101

\section{Pendahuluan}

Berdasarkan data Badan Pelayanan Statistik tahun 2017, jumlah penduduk Provinsi Banten berjumlah 12, 5 juta orang. Mayoritas 94,62\% penduduk Provinsi Banten menganut kepercayaan Agama Islam. Sektor Industri pengolahan setidaknya menyumbangkan 49,75\% Produk Domestik Regional Bruto, persentase tersebut diikuti dengan sektor perdagangan, hotel dan restoran sebesar $17,13 \% .{ }^{1}$ Ini menunjukkan bahwa sektor industri memliliki peran penting dalam memenuhi kebutuhan masyarakat muslim akan produk maupun jasa yang tidak bertentangan dengan ajaran agama Islam. Peran tersebut diwujudkan dalam bentuk Industri Halal, yang bermakna bahwa menjalankan kegiatan ekonomi yang mengolah bahan mentah, bahan baku, barang setengah jadi atau barang jadi menjadi barang bermutu tinggi dalam penggunaannya berdasarkan prinsip halal yang termuat pada Sistem Jaminan Halal. ${ }^{2}$

Peran penting sektor industri dalam memenuhi hajat hidup masyarakat muslim Banten hendaknya harus dibarengi dengan upaya pengembangan Industri dengan mengedepankan nilai ketaatan pada Tuhan. Program pengembangan Industri halal sejatinya telah dimulai sejak lahirnya Undang-undang Sertifikasi Jaminan Halal pada tahun 2014. Sampai dengan saat ini, telah bermunculan Industri Halal, baik dalam skala menengah kecil maupun menengah ke atas. Untuk pengembangan Industri halal di Provinsi Banten, maka penulis merasa bahwa perlu dilakukan penelitian yang berjudul Kajian Ekonomi Syariah Terhadap Sistem Perencanaan, Pelaksanaan dan Pengawasan Industri Halal di Wilayah Provinsi Banten, guna mendapatkan gambaran objektif dan langkah alternatif yang dapat diajukan pada kegiatan Industri Halal di Provinsi Banten

Penelitian ini didasarkan pada hipotesis bahwa dalam kegiatan Indsutri Halal senantiasa dijalankan dengan adanya perencanaan, metode pelaksanaan serta upaya pengawasan guna mempertahankan nilai halal pada suatu produk atau jasa dan juga output hasil produksi. Perencanaan dilakukan guna menentukan standar pelayanan maupun standar produksi yang sesuai dengan ketentuan halal lagi thayyib. Disamping itu, perencanaan juga digunakan untuk menentukan perencanaan kegiatan dan metode dalam menghasilkan suatu produk dengan kualifikasi halal. Dalam sistem pelaksanaan, industri halal senantiasa dihadapkan pada adanya kendala atau penghambat, sehingga menuntut adanya upaya antisipatif dalam mengentaskan kendala atau hambatan tersebut. Sedangkan dalam sistem pengawasan, hal tersebut tidak dapat berjalan sendiri. Industri halal secara normatif senantiasa mendapatkan pengawasan dari Majelis Ulama Indonesia dalam mempresentasikan konsep halal pada Masyarakat.

1 Data BPS Provinsi Banten tentang unlah Penduduk Provinsi Banten, lihat pada laman https://banten.bps.go.id/, diakses pada 5 April 2019, pukul 21.00.

${ }^{2}$ Ahmad Hasan Ridwan, dkk, "The Halal Concept and its Implication upon Green Industry in Halal Implementing Countries (Indonesia, Malaysia and Singapore)", Penelitian Terapan dan Pengembangan Global, (Universitas Islam Negeri Sunan Gunung Djati, Bandung, 2018), hlm. 26-27. 
Konsep halal li dzatihi saja tidak cukup untuk memberikan perlindungan kepada masyarakat. Hal ini didasari pada adanya perintah menjalankan kegiatan ekonomi berlandaskan pada konsep halalan thayyibah. Thayyib bermakna baik, baik bagi diri sendiri, maupun bagi orang lain. Industri memberikan dampak tidak hanya pada pemenuhan kebutuhan hidup, namun dilihat pada aspek yang lebih luas, kegiatan industri mampu memberikan dampak pada ekonomi masyarakat dan juga lingkungan dimana masyarakat tinggal.

\section{Metode Penelitian}

Penelitian ini menggunakan jenis penelitian kualitatif deskriptif. Bogdan dan Tylor mendefinisikan penelitian kualitatif sebagai prosedur penelitian yang menghasilkan data deskriptif berupa kata-kata tertulis atau lisan dari orang-orang atau perilaku yang diamati. ${ }^{3}$ Metode kualitatif deskriptif menyesuaikan pendapat antara peneliti dan informan. Pemilihan metode ini dilakukan karena analisisnya tidak bisa dalam bentuk angka dan peneliti lebih mendeskripsikan segala fenomena yang ada dimasyarakat secara jelas. ${ }^{4}$

Penelitian ini memiliki maksud untuk memahami fenomena sistem perencanaan, pengawasan dan pelaksanaan Industri Halal di Provinsi Banten. Penelitian ini akan mendeskripsikan hal tersebut dalam bentuk kata-kata dan bahasa. Penelitian ini juga memuat fakta yang terjadi di lapangan serta gambaran mengenai peranan LPPOM MUI Provinsi Banten dalam mengawal industri halal di Provinsi Banten, agar kemudian dapat dikaji secara mendalam dengan pendekatan-pendekatan teoritis.

\section{Sistem Perencanaan dan Pelaksanaan Industri Halal}

Dalam ilmu manajemen, perencanaan yang ditujukan untuk mengarahkan jalannya pelaksanaan, agar tujuan yang telah ditetapkan itu dapat tercapai secara efektif dan efisien seringkali dikenal dengan istilah perencanaan koordinatif. Perencanaan ini mempunyai cakupan semua aspek operasi (tujuan, sasaran, standard operational procedure) dalam suatu sistem yang menyepakati pelaku usaha untuk senantiasa mematuhi kebijakan-kebijakan yang telah ditetapkan pada tingkat perencanaan strategis. Perencanaan strategis merupakan upaya untuk mempersiapkan seperangkat desisi di masa yang akan datang untuk mempengaruhi keseluruhan kegiatan yang dilaksanakan oleh suatu organisasi. $^{5}$

Ditinjau dari segi tujuannya, perencanaan industri halal yang menjalankan sistem jaminan halal adalah untuk menjaga kesinambungan proses produksi halal, sehingga

\footnotetext{
${ }^{3}$ Lexy J. Moleong, Metode Penelitian Kualitatif, (Jakarta : Rosda Karya, 2010), hlm. 4.

${ }^{4}$ Suharsimi Arikunto, Prosedur Penelitian Ilmiah Dasar, (Bandung: Tarsito, 1985), hlm. 129.

${ }^{5}$ Idocdi Anwar, dkk yang dikutip dari H. Ozbehkan (D. Cleland \& W.R king. 1975), hlm, 31.
} 
Ahyakudin, Suja'i, M. Abduh, Sistem Perancangan, Pelaksanaan dan Pengawasan Industri... | 103

produk yang dihasilkan dapat selalu dijamin kehalalannya sesuai dengan ketentuan Jaminan Produk Halal. Oleh karena itu, penulis melihat terdapat beberapa prinsip dasar yang harus diperhatikan oleh para pelaku industri sebagai langkah awal berjalannya kegiatan industri.

Prinsip pertama ialah prinsip mengedepankan maqashid al-syariah. Maqashid alsyariah secara bahasa memiliki makna maksud-maksud dari ketentuan syariah. Arti dari Maqashid al-syariah ialah gagasan yang senantiasa dijadikan patokan dalam konsep hukum Islam yang menegaskan bahwa ketentuan Allah senantiasa ditujukan untuk mencapai maksud atau tujuan-tujuan tertentu. Tujuan-tujuan tersebut dapat ditemukan dalam sumber utama hukum Islam yakni Qur'an dan Sunnah, serta harus senantiasa dipelihara dalam menentukan kebijakan yang berkaitan dengan suatu perkara. ${ }^{6}$ Dalam hasil penelusuran peneliti di lapangan, peneliti melihat bahwa kualitas halal dalam produk tidaklah semata untuk mencapai kepentingan pemasaran sebagaimana yang sering didiskusikan pada forum-forum tertentu. Jauh dari itu, Sate Bandeng Aminah dan Cilok Ceu'tuti telah mampu menanamkan kesadaran tinggi akan esensi ketauhidan dalam kegiatan bisnisnya. Hal ini selaras dengan tujuan ekonomi islam, yakni tujuan ekonomi yang mampu mengajarkan nilai ketaatan diri kepada Tuhan.

Pelaksanaan Industri Halal bagi perusahaan yang memiliki sertifikat halal MUI harus senantiasa mempunyai maksud memelihara kesucian agama, akal/pikiran, jiwa, keturunan, dan harta. Hal ini merupakan komponen dharuriyyat yang harus senantiasa mendapatkan perhatian utama. Dharuriyyat merupakan komponen utama yang harus senantiasa dijaga oleh setiap manusia dalam menciptakan kemaslahatan tidak hanya bagi dunianya, namun juga pada nilai-nilai keagamaan. ${ }^{7}$

Pelaku industri harus menghilangkan pandangan bahwa kegiatan mendaftarkan produknya untuk mendapatkan sertifikasi halal hanya semata-mata untuk kepentingan pemasaran belaka. Kesucian dalam menjalankan nilai-nilai agama dari kegiatan konsumsi produk-produk yang memenuhi standar halal merupakan suatu kondisi yang sangat dibutuhkan bagi setiap ummat. Kebutuhan yang selama ini dinikmati diharapkan mampu memberikan kondisi terbaik pada jasmani dan pikirannya.

Hal-hal yang peneliti dapatkan pada beberapa sampel yang telah ditentukan, ditemukan bahwa alasan utama bagi pelaku industri mikro dalam menjalankan sertifikasi halal pada produknya didasari pada adanya kesadaran untuk memahami bagaimana instrumen serta langkah yang harus dilakukan bagi pelaku usaha dalam mempresentasikan produk mereka agar unsur kehalalan produk dapat terpenuhi. Kemudian untuk

\footnotetext{
${ }^{6}$ Adis Duderija, Contemporary Muslim Reformist Thought and Maqāṣid cum Mașlaḥa Approaches to Islamic Law: An Introduction. (Maqasid al-Shari'a and Contemporary Reformist Muslim Thought: An Examination. Springer, 2014), hlm. 2.

${ }^{7}$ Ade Iskandar Nasution. "Pendekatan Maqashid Syari'ah dalam Praktik Pembiayaandi Koperasi Peternak Sapi Bandung Utara (KPSBU)." Jurnal As-Syari'ah Vol. 21 No. 1 (Juni 2019): hlm. 34-35.
} 
mengukur kemampuan pelaku usaha dalam mempresentasikan produk halal, dibutuhkan auditor dari LPPOM MUI Provinsi Banten untuk memberikan penilaian terhadap produk agar sesuai dengan kualifikasi halal yang diinginkan.

Menurut Euis (Owner Cilok Ceu' Tuti), "ketentuan halal merupakan nilai utama yang harus dipahami bagi pelaku usaha dalam menghasilkan suatu produk. Usaha mendapatkan keuntungan harus sejalan dengan perintah agama agar senantiasa mendapatkan keberkahan dan tidak meninggalkan keburukan bagi orang lain". Berkenaan dengan nilai tersebut maka aspek amanah dalam manjalankan kegiatan industri juga merupakan instrumen yang wajib untuk dilaksanakan.

Prinsip kedua ialah amanah. Implementasi prinsip amanah dalam menjalankan kegiatan industri diwujudkan dengan sikap senantiasa jujur serta transparan dalam menguraikan aktivitas produksi yang dilakukan di perusahaannya. ${ }^{8}$ Tantangan yang dimiliki oleh para pegiat Industri di provinsi Banten ialah seiring dengan adanya dinamisasi dalam ketersediaan bahan baku dan bahan lainnya yang berkaitan dengan unsur produksi, diharapkan pelaku industri tidak bersikap curang atau dhalim dalam menghadapi kelangkaan bahan baku, maupun tingginya harga bahan baku di beberapa periode. Transparansi para pelaku usaha dalam industri dapat diwujudkan dengan memberikan keterbukaan informasi terhadap masyarakat akan bahan baku dalam barang produksi yang dihasilkannya. Hal ini bertujuan agar masyarakat dapat melakukan penilaian dan pengujian terhadap kadar zat yang terkandung dalam suatu produk. Sehingga jika dikemudian hari jika dapat ditemukan perbedaan yang signifikan dan berpotensi pada adanya penggunaan bahan terlarang, maka alat bukti untuk melakukan tuntutan dapat terpenuhi. Jujur dikenal juga dengan istilah amanah. Amanah yang merupakan sifat yang mulia, merupakan sifat yang wajib untuk dimiliki semua muslim. Tidak hanya terkait dengan hubungannya dengan manusia, tetapi juga bersifat amanah terhadap semua yang diberikan Allah. Dalam surat al Anfal ayat 27 Allah berfirman, "Wahai orang-orang yang beriman! Janganlah kamu mengkhianati Allah dan Rasul, dan (juga) janganlah kamu menkhianati amanah yang telah dipercayakan keadamu, sedang kamu mengetahui".

Dalam aktualisasi industri halal, LPPOM MUI memberikan kepercayaan kepada industri atau perusahaan produksi dalam penyusunan manual book sistem jaminan halal berdasarkan kondisi nyata internal perusahaan. Manual book sistem jaminan halal pada Industri dan arsip terkait senantiasa terdokumentasikan agar dapat dijadikan sebagai acuan dalam penyelenggaraan industri halal. Hal ini juga agar pihak yang berkepentingan mudah untuk melakukan penelusuran terkait dengan standar kerja industri dalam menghasilkan produk halal.

${ }^{8}$ Ikhwan Aulia Fatahillah, Kontribusi Industri Halal Terhadap Perkembangan Industri Ramah Lingkungan (Green Industry) di Indonesia, (Bandung: 2017), hlm. 112. 
Implementasi Industri halal merupakan tanggungjawab bersama dari level manajemen puncak sampai dengan karyawan, sehingga Sistem Jaminan Halal yang ada pada industri harus disosialisasikan dengan baik dan menyeluruh di lingkungan perusahaan. Pada Sate Bandeng Aliyah telah diterapkan aturan ketat terkait dengan kriteria pekerja sampai dengan teknik pengolahan bahan baku. Meskipun tidak banyak pekerja yang dapat diberdayakan pada industri tersebut, namun kriteria tenaga kerja yang ada pada industri tersebut diberlakukan dengan standar yang berbeda pada umumnya. Pekerja yang ada pada sate bandeng aliyah dituntut untuk memiliki pemahaman dan aktualisasi keagamaan yang baik. Menurut owner Sate Bandeng Aliyah: "pekerja di sate bandeng awliyah umumnya memiliki latar belakang pesantren, sedikitnya mereka memahami apa boleh dilakukan dan apa yang tidak boleh dilakukan dalam usaha. Kita pengennya mereka punya pemahaman tentang menjaga agar produk tidak melenceng dari ketentuan halal".

Dalam aktualisasi produk halal Kopi bubuk Leuit Baduy sangat memperhatikan penggunaan bahan baku serta proses produksi. Ketentuan penggunaan bahan-bahan non alami (kimia) sebisa mungkin dihindari guna menjaga esensi alamiah yang sejalan dengan nilai hidup budaya Baduy. Penggunaan bahan-bahan alami juga tetap mendapatkan pengawasan agar zat-zat alami yang bertentangan dengan ketentuan halal tidak tercampur pada produk. Kopi bubuk Leuit Baduy juga telah menjalankan uji laboratorium pada tahun 2018 yang membuktikan bahwa sekalipun tidak menggunakan pengawet kimiawi, namun masa ketahanan dari produk ini mampu mencapai masa 400 hari pada suhu ruang.

Dalam menjalankan pengawasan tersebut, pemilik Kopi bubuk Leuit Baduy memiliki peran langsung dengan senantiasa mengawasi jalannya kegiatan produksi. Sistem pendataan bahan baku datang, penggunaan bahan baku yang ada, serta kuantitas dan kualitas produksi diterapkan sebagai instrumen pengawasan perusahaan dalam menjamin tidak adanya bahan baku yang terlarang masuk pada kegiatan produksi.

Melihat pada hal tersebut, penulis merasa bahwa kesadaran dalam menjalankan prinsip kehati-hatian dalam setiap kegiatan produksi perlu pula untuk dijalankan dalam perusahaan. Tidak hanya mengeluarkan aturan-aturan tekhnis semata namum juga harus dibarengi dengan kualifikasi pengetahuan spiritual mendalam akan kegiatan produksi oleh pekerja. Dalam beberapa sektor produksi, hal ini dapat memberikan peran vital guna terciptanya kualitas produk yang memenuhi esensi halalan thayyibah. Salah satu contoh jika produk industri tersebut berasal dari daging hewan ternak yang disembelih di dalam pabrik/industri. Sekalipun telah ada instrumen tertulis tentang tata cara penyembelihan, namun jika pekerja kehilangan akal dalam melaksakan penyembelihan (akibat meminum minuman keras sebelum masuk jam operasional), maka hal tersebut masuk pada kategori penyembelihan yang tidak sesuai dengan syariat.

Secara keseluruhan, Industri Halal di Provinsi Banten menunjukkan peningkatan yang sangat signifikan. Pada tahun 2017, produk olahan yang mendapatkan sertifikasi 
halal hanya berada pada kisaran 3.500 produk. Selang dua tahun, sampai dengan Agustus 2019 setidaknya produk olahan yang telah tersertifikasi oleh LPPOM MUI Provinsi Banten telah mencapai lebih dari 9787 produk. Hal ini tentu menunjukkan pada tren positif, meskipun di lapangan masih banyak pula produk yang belum tersertifikasi oleh MUI. Semakin tingginya keinginan pelaku industri untuk mengejar sertifikasi halal pada produknya tentu mampu memberikan rasa aman dan tenang bagi setiap masyarakat dalam mengonsumsi produk. Maka dari itu, harapan untuk menjangkau industri kecil yang lebih luas diharapkan dapat terwujud dengan adanya mekanisme sertifikasi yang lebih murah dan mudah.

\section{Pengawasan Industri Halal di wilayah Provinsi Banten}

Dalam memenuhi operasionalisasi industri yang efektif, efisien dan ekonomis, setiap industri perlu melakukan kegiatan integrasi perencanaan produksi dan sistem pengawasan produksi. Hal ini dilakukan agar kualitas mutu yang ada pada sistem perencanaan berjalan sesuai dengan apa yang semestinya.

Pada industri halal, pengawasan yang menjadi ciri khas utamanya ialah melakukan integrasi terhadap rencana produksi agar instrumen halal pada produk berjalan sesuai dengan ketentuan dan harapan terciptanya produk halal. Pengawasan dapat dilakukan dengan memastikan dokumen halal maupun asal usul bahan baku, pengawasan alat produksi, melakukan uji laboratorium terhadap proses kimiawi yang pada suatu produk, bahkan melakukan pengecekan mutu terhadap dampak negatif yang dapat saja ditimbulkan dari produk tertentu tersebut.

Pengawasan produk halal dari industri pada provinsi Banten dalam skala makro dilaksanakan oleh LPPOM MUI Provinsi Banten dibantu dengan elemen masyarakat. Dalam pengawasan industri, LPPOM MUI senantiasa melakukan sidak terhadap industri yang telah mendapatkan sertifikasi jaminan produk halal. Kegiatan tersebut dapat dilakukan minimal satu kali dalam dua tahun pada masing-masing industri yang tersertifikasi. Hal ini dilakukan untuk menjaga konsistensi industri dalam menghasilkan produk yang sesuai dengan ketentuan halal. Dasar hukum dalam pengawasan ini dilakukan berdasarkan Undang-undang Nomor 13 Tahun 2014 tentang Jaminan Produk Halal.

Dalam proses inspeksi mendadak (sidak) tersebut jika ditemukan adanya unsur pelanggaran fatal yang berkaitan dengan penggunaan bahan yang diharamkan secara sengaja, maka LPPOM MUI Provinsi Banten akan mencabut Sertifikasi Halal pada produk berikut sertifikasi Sistem Jaminan Halal pada perusahaannya. Temuan LPPOM MUI tersebut selanjutnya akan disampaikan kepada BPPOM maupun dinas perindustrian Provinsi untuk mendapatkan tindak lanjut yang lebih pantas.

Dalam beberapa kasus, peran masyarakat dalam pengawasan juga telah banyak membantu LPPOM MUI untuk melakukan tindakan terhadap produk yang memiliki 
pelanggaran penggunaan zat maupun proses dalam produksi. Dengan adanya laporan dari masyarakat yang dikuatkan dengan hasil laboratorium telah mampu memberikan informasi temuan pelanggaran pada kehalalan produk yang dilakukan industri yang telah bersertifikasi.

Beberapa temuan yang sempai disampaikan narasumber kepada kami diantaranya ialah ; pertama, kasus tulang babi yang ditemukan pada filter air pada produk air mineral kemasan yang ada di daerah kota Tangerang. Temuan ini diawali dengan sidak yang dilakukan LPPOM MUI Banten sebagai rutinitas instansi. Pada awal pengajuan sertifikasi, sedianya produk air mineral tersebut telah memenuhi kualifikasi produk halal karna tidak ditemukan bahan maupun alat yang berpotensi pada zat-zat yang diharamkan. Seiring dengan berjalannya waktu, industri melakukan penggantian filter air yang tanpa disadari bahwa filter tersebut telah dimodifikasi sehingga mengandung unsur DNA babi. Terhadap peristiwa tersebut, LPPOM MUI memerintahkan untuk menghentikan kegiatan produksi dan membekukan sertifikasi jaminan halal yang telah ada pada industri tersebut. ${ }^{9}$

Kasus kedua ialah salah satu rumah makan bakso yang ada di wilayah Kota Serang yang sedianya produk yang dihasilkan oleh rumah makan tersebut telah sesuai dengan ketentuan produk halal. Melihat pada prosesnya pun telah dilakukan dengan baik dan benar sehingga tidak nampak cacat produk pada rumah makan tersebut. Namun pada suatu waktu LPPOM MUI menemukan adanya unsur DNA babi pada produk rumah makan tersebut berdasarkan laporan yang diterima dari masyarakat. Dalam merespon hal tersebut, LPPOM MUI melakukan kajian terhadap penggunaan bahan baku yang ada pada produk rumah makan tersebut, hasil yang didapatkan justru negatif, artinya bahan baku yang ada tidak menunjukkan adanya zat yang diharamkan, bahkan daging yang semula dikhawatirkan tidak sesuai ketentuan halal justru telah tersertifikasi, dan memiliki dokumen kehalalan yang baik. Hal demikian juga terjadi pada bumbu-bumbu yang ada pada rumah makan tersebut, hasilnya tidak ada yang positif zat haram. Belakangan diketahui bahwa penyebab adanya zat haram pada produk bakso tersebut berasal dari proses yang terjadi di luar rumah makan tersebut. Akibat rusaknya mesin penggiling yang ada pada rumah makan tersebut, para pekerja berinisiatif untuk melakukan penggilingan daging yang telah tersertifikasi halal pada tempat penggilingan daging umum yang belum tersertifikasi halal. ${ }^{10}$

Dampak dari kegiatan penggilingan daging halal pada tempat penggilingan yang tidak tidak tersertifikasi halal dan higienis tersebut, menyebabkan terjadinya percampuran antara puluhan kilogram daging halal dan daging sisa-sisa penggilingan sebelum-

\footnotetext{
${ }^{9}$ Berdasarkan wawancara yang dilakukan dengan Irhamni, perwakilan LPPOM MUI Provinsi Banten pada 22 Agustus 2019 pukul 12.31 WIB.

${ }^{10}$ Berdasarkan wawancara yang dilakukan dengan Irhamni, perwakilan LPPOM MUI Provinsi Banten pada 22 Agustus 2019 pukul 12.31 WIB.
} 
nya yang menempel pada mesin penggiling. Karena proses penggilingan pada tempat tersebut tidak dilakukan pengecekan asal usul daging maka yang terjadi adalah menempelnya DNA daging yang tidak halal pada daging giling rumah makan tersebut. Disinilah muara ditemukannya DNA daging tidak halal oleh masyarakat. ${ }^{11}$

Melihat pada dua peristiwa diatas, maka pertimbangan ketat dalam melihat suatu produk harus senantiasa pada didasari pada tiga aspek. Aspek Pertama, ialah Haram li Dzatihi yakni keharaman pada suatu produk yang terletak pada dzat/barang (makanan /minuman) yang diharamkan, baik yang diharamkan oleh al-Quran, seperti (Babi, Khamar, Darah, Bangkai dan sembelihan bukan atas nama Allah (dihukumi sama dengan bangkai); yang diharamkan berdasarkan al-Sunnah (hadits) seperti: Binatang buas, Burung Elang, Keledai Jinak maupun yang diharamkan berdasarkan ijtihad fuqaha karena menjijikkan atau karena ada hadits yang melarang membunuhnya.

Sampai dengan saat ini, esensi keharaman pada produk industri masih mengacu pada aspek kandungan zat semata. Hal ini merupakan cara termudah yang dapat dilakukan mengingat setiap instrumen dalam meneliti kandungan zat telah dimiliki oleh LPPOM MUI Provinsi maupun Pusat. Namun kendala yang dihadapi ialah jika LPPOM MUI pasif dalam melakukan pengawasan maka masyarakat pun akan terjebak pada kondisi bercampurnya zat yang diharamkan pada produk yang akan dikonsumsi. Kalaupun masyarakat hendak terlibat dalam pengawasan tersebut, minimal mereka harus memperoleh hasil laboratorium yang biayanya cukup mahal, yakni di kisaran Rp. 2.500.000,- . Melihat hal ini, masyarakatpun akhirnya enggan untuk melaporkan kejanggalan yang ada pada produk olahan.

Kedua, Haram li Ghayrihi yakni keharaman karena faktor lain, barangnya sendiri secara dzatiyah adalah halal (mubah), tetapi diperoleh dengan cara mencuri atau menipu, seperti perolehannya yang dilarang/diharamkan seperti sapi, kambing, ayam hasil mencuri atau dibeli dari uang hasil curian (tidak halal). ${ }^{12}$ Bagi pelaku usaha seringkali dihadapkan pada dinamisasi ketersedian bahan baku maupun bahan penunjang lain dalam produksi. Jika kemudian pengawasan terhadap kegiatan tersebut lemah, maka dalam menghadapi dinamisasi tersebut pelaku usaha/industri dapat saja melakukan upaya manipulasi menggunakan bahan-bahan yang tidak tercantum pada label kemasan dan manual book pengajuan sertifikasi untuk mendapatkan keuntungan lebih. Salah satu contoh ialah dalam sosis daging, BPPOM telah menentukan standar minimal proteinnya ialah 13\%. Jika menggunakan daging yang dengan grade baik maka kadar protein tersebut dapat tercapai. Namun jika grade daging baik tersebut ternyata sulit untuk diperoleh sedangkan permintaan pasar sedang berada pada titik baik maka untuk memenuhi kualitas produk industri melakukan cara mencampurkan daging grade

${ }^{11}$ Berdasarkan wawancara yang dilakukan dengan Irhamni, perwakilan LPPOM MUI Provinsi Banten pada 22 Agustus 2019 pukul 12.34 WIB.

${ }^{12}$ Ahmad Isa Asyur, Fiqih Islam Praktis, (Solo: Pustaka Mantik, 1995), hlm. 28. 
kurang baik dengan jeroan. Bagi sebagian orang, jeroan dapat menjadi momok yang menakutkan karena dapat memicu berbagai penyakit.

Terhadap upaya yang demikian jika kemudian terdapat campuran bahan lain yang tidak tercatat dan terdata pada izin maupun kemasan, namun kemudian mampu menimbulkan dampak negatif bagi konsumen maka Industri tersebut telah melakukan suatu kegiatan yang dalam istilah ekonomi islam disebut sebagai Tadlis. Tadlis adalah salah satu bentuk penipuan dalam berdagang, merupakan bentuk ketidakjujuran seorang pedagang dalam menjalankan usahanya. Terhadap aktivitas tersebut dzat pada produk dapat saja tetap terjaga kehalalnnya, namun bagi pelaku manipulasi tersebut akan menjadi suatu kegiatan yang dilarang dalam ekonomi Islam.

Ketiga, Haram li 'Aqibatih yakni barang atau dzatnya tidak termasuk yang diharamkan langsung baik oleh al-Quran atau al-Sunnah, tetapi jika dikonsumsi akan menimbulkan keburukan atau berakibat sama dengan yang diharamkan secara dzatiyah. ${ }^{13}$ Dalam aspek ini pelaku industri juga harus memikirkan akan dampak jangka panjang jika produknya dikonsumsi oleh masyarakat. Terhadap beberapa kondisi tertentu, penggunaan bahan pengawet kimiawi dapat memberikan dampak negatif terhadap kondisi tubuh seseorang, oleh karenanya inovasi yang dihasilkan oleh pelaku industri hendaknya juga harus mampu memperhatikan aspek kesehatan bagi konsumen. Orientasi untuk mendapatkan keuntungan semata tanpa memperhatikan akibat dari suatu kegiatan usaha bukanlan merupakan tujuan ekonomi Islam.

Dengan demikian, penulis merasa bahwa upaya yang dilakukan penyelia halal maupun penanggungjawab dalam memastikan dokumen halal, pengawasan alat produksi, dan pengecekan mutu produk merupakan komponen wajib yang harus dilaksanakan oleh industri agar tidak terjadi mal function dari sertifikasi halal oleh MUI. Sehingga dalam proses tersebut para penanggungjawab harus benar-benar memiliki pemahaman mendalam pada aspek li dzatihi, li ghairihi, dan li aqibatihi.

\section{Mengatasi Kendala dalam Kegiatan Industri Halal}

Kendala yang dihadapi oleh industri halal di Provinsi Banten pada umumnya dialami oleh Industri dengan skala Usaha Kecil Mikro. Hal ini diakibatkan pada banyaknya komponen utama yang harus dipenuhi dalam manual book Sistem Jaminan Halal. Berkaitan dengan hal tersebut, LPPOM MUI Provinsi Banten menyatakan bahwa tidak mesti seluruh komponen dalam SJH tersebut terpenuhi, khusunya bagi perusahaan atau industri yang belum memiliki penyelia halal dalam kegiatan industrinya.

${ }^{13}$ Ahmad Hasan Ridwan, dkk, The Halal Concept and its Implication upon Green Industry in Halal Implementing Countries (Indonesia, Malaysia and Singapore), Penelitian Terapan dan Pengembangan Global, (Bandung: Universitas Islam Negeri Sunan Gunung Djati, 2018), hlm. 26-27. 
Penyelia Halal dalam kegiatan industri umumnya dimiliki oleh perusahaan menengah atas yang telah menjalankan sistem manajemen kompleks dalam perusahaannya. Adanya penyelia halal dalam kegiatan industri mampu berperan sebagai pengawas kegiatan produksi agar produk yang dihasilkan senantiasa terjaga kehalalannya. Di samping itu, penyelia halal juga memiliki peran untuk melakukan pelaporan terhadap penyelenggaraan halal pada industri. Permohonan halal terhadap varietas produk lainnya juga dapat diatur dan disiapkan oleh unit penyelia halal. ${ }^{14}$

Meskipun penyelia halal tidak tersedia pada industri kecil, instrumen terkait dengan komitmen dan kualifikasi produk halal harus terpenuhi dan diberlakukan secara ketat sama halnya dengan industri besar lainnya. Uji Laboratorium dan proses audit internal dilapangan juga perlu dilakukan.

Di samping masalah penyelia halal, masalah tarif dalam sertifikasi halal juga dirasa masih cukup tinggi bagi beberapa unit usaha. Pemilik cilok ceu' tuti salah satunya mengungkapkan bahwa biaya sebesar kurang lebih Rp. 2,5 juta dirasa masih cukup tinggi baginya untuk dipenuhi. Bahan baku dan alat produksi dalam usaha cilok yang dijalankan justru menurutnya jauh lebih murah dibandingkan dengan biaya sertifikasi. ${ }^{15}$

Menurut penulis, hal diatas dapat dijadikan sebagai alasan utama bagi para pelaku industri kecil untuk tidak mendaftarkan produknya pada sistem jaminan halal yang ada pada MUI. Kesadaran akan produk halal tentunya menjadi sebuah keharusan bagi pelaku usaha. Sekalipun produk insudti kecil tidak mendapatkan sertifikasi, banyak yang menganggap bahwa produk mereka telah halal dalam bahan baku maupun prosesnya. Padahal jika dikaji secara seksama, aspek tracking dokumen dan uji laboratorium pada sistem jaminan halal dapat dijadikan patokan utama bahwa prnsip kehati-hatian dalam menjaga produk tetap halal telah diselenggarakan dengan baik.

Ditinjau dari segi pelaku industri kecil, mereka biasanya juga bukan orang-orang teknis yang mengerti betul mengenai proses produksi. Kebanyakan dari mereka adalah berlatar belakang bisnis atau marketing. Ditinjau dari segi kehalalan, persoalan ini menjadi cukup serius. Auditor LPPOM MUI menginginkan informasi selengkap-lengkapnya mengenai asal-usul bahan baku dan bahan tambahan yang digunakan dalam suatu produk.

Asal-usul ini menjadi sangat penting untuk meyakinkan bahwa tidak ada bahan haram yang masuk mencemari produk tersebut. Jika tidak diketahui asal-usulnya, maka auditor tidak bisa memastikan status kehalalannya. Biasanya ada sedikit kesenjangan antara kepentingan pemeriksaan halal dengan pihak pemasok atau produsen tersebut. Kedala lainnya dalam proses audit internal mutu produk ini ialah adanya perasaan takut

\footnotetext{
${ }^{14}$ Berdasarkan wawancara yang dilakukan dengan Irhamni, perwakilan LPPOM MUI Provinsi Banten pada 22 Agustus 2019 pukul 12.40 WIB.

${ }^{15}$ Berdasarkan wawancara yang dilakukan dengan Euis, Pemilik Usaha Cilok Ceu' Tuti di Kota Tangerang pada 9 September 2019 pukul 15.20 WIB.
} 
Ahyakudin, Suja'i, M. Abduh, Sistem Perancangan, Pelaksanaan dan Pengawasan Industri... | 111

pada produsen atau pemasok bahwa dengan memberikan data selengkap-lengkapnya dalam pemeriksaan halal bisa mengancam kerahasiaan pelaku usaha, karena pada dasarnya setiap industri atau pelaku usaha selalu mempunyai rahasia data produk, yang tidak ingin diketahui pihak lain. Sebaliknya pemeriksaan halal menghendaki data selengkaplengkapnya guna mengetahui asal-usul bahan tersebut.

Kesenjangan ini sebenarnya tidak harus menjadi masalah besar. Apa yang diinginkan dalam pemeriksaan halal hanyalah bersifat kualitatif. Artinya pemeriksaan halal hanya menginginkan apa saja bahan yang masuk dalam produk tersebut, tanpa harus mengetahui berapa banyak atau perapa persen bahan tersebut digunakan. Selain itu auditor LPPOM MUI juga memiliki kode etik yang sama sekali tidak membolehkan pengungkapan data perusahaan kepada pihak lain yang tidak berkepentingan.

\section{Simpulan}

Perencanaan dalam industri menjalankan sistem jaminan halal adalah dimaksudkan untuk menjaga kesinambungan proses produksi halal, sehingga produk yang dihasilkan dapat selalu dijamin kehalalannya sesuai dengan ketentuan LPPOM MUI. Oleh karena itu, industri hendaknya memperhatikan aspek Maqashid Syariah dan aspek amanah sebagai upaya memberikan kepastian bagi masyarakat bahwa produk yang dihasilkan oleh industri telah sesuai dengan ketentuan halal.

Implementasi Industri halal merupakan tanggungjawab bersama dari level manajemen puncak sampai dengan karyawan, sehingga Sistem Jaminan Halal yang ada pada industri harus disosialisasikan dengan baik dan menyeluruh di lingkungan perusahaan. Kesadaran dalam menjalankan prinsip kehati-hatian dalam setiap kegiatan produksi perlu pula untuk dijalankan dalam perusahaan. Tidak hanya mengeluarkan aturan-aturan tekhnis semata namum juga harus dibarengi dengan kualifikasi pengetahuan spiritual mendalam akan kegiatan produksi oleh pekerja. Dalam beberapa sektor produksi, hal ini dapat memberikan peran vital guna terciptanya kualitas produk yang memenuhi esensi halalan thayyibah.

Sistem Pengawasan yang menjadi ciri khas pada industri halal ialah melakukan integrasi terhadap rencana produksi agar instrumen halal pada produk berjalan sesuai dengan ketentuan dan harapan terciptanya produk halal. Pengawasan dapat dilakukan dengan memastikan dokumen halal maupun asal usul bahan baku, pengawasan alat produksi, melakukan uji lab terhadap proses kimiawi yang pada suatu produk, bahkan melakukan pengecekan mutu terhadap dampak negatif yang dapat saja ditimbulkan dari produk tertentu tersebut.

Pengawasan produk halal dari industri pada provinsi Banten dalam skala makro dilaksanakan oleh LPPOM MUI Provinsi Banten dibantu dengan elemen masyarakat. Upaya yang dilakukan penyelia halal maupun penanggungjawab dalam memastikan 
dokumen halal, pengawasan alat produksi, dan pengecekan mutu produk merupakan komponen wajib yang harus dilaksanakan oleh industri agar tidak terjadi mal function dari sertifikasi halal oleh MUI. Sehingga dalam proses tersebut para penanggungjawab harus benar-benar memiliki pemahaman mendalam pada aspek li dzatihi, li ghairihi, dan li aqibatihi yang menjadi komponen utama dalam sistem halal menurut pandangan syariah.

Kendala yang dihadapi dalam penyelenggaraan industri halal lebih sering dihadapi oleh pelaku industri mikro dan kecil. Biaya sebesar kurang lebih Rp. 2,5 juta dirasa masih cukup tinggi untuk dipenuhi. Kendala selanjutnya ialah adanya perasaan takut pada produsen atau pemasok bahwa dengan memberikan data selengkap-lengkapnya dalam pemeriksaan halal bisa mengancam kerahasiaan pelaku usaha. Berkaitan dengan rahasia perusahaan ini, auditor LPPOM MUI juga memiliki kode etik yang sama sekali tidak membolehkan pengungkapan data perusahaan kepada pihak lain yang tidak berkepentingan.

\section{DAFTAR PUSTAKA}

Alim, Haidar Tsani. Analisis Potensi Pariwisata Syariah Dengan Mengoptimalkan Industri Kreatif di Jawa Tengah Dan Yogyakarta. Yogyakarta: Universitas Diponegoro, 2017.

Arif, Ahmad Jauhar. Peran Agama dan Etika dalam Konservasi Sumber Daya Alam dan Lingkungan Hidup. Bogor: LIPI, 2003.

Awang, M. D., Noor, M. N., Muhammad , J., Abdullah, A., Rahman, S., \& Yahya, M. H. "Acceptance and Application of Islamic Financial Planning among Small and Medium Enterprises Halal Operator in Peninsular of Malaysia." IJASOS- International EJournal of Advances in Social Sciences, Volume 2 (Juni 2017): 6.

Bohari, A. M., Cheng, W. H., \& Fuad, N. "An Analysis on the Competitiveness of Halal Food Industry in Malaysia: An Approach of SWOT and ICT Strategy." Malaysia Journal of Society and Space Volume 9, issue 1 (2013): 1-11.

Gillani, S. H., ljaz, F., \& Khan, M. M. "Role of Islamic Financial Institutions in Promotion of Pakistan Halal Food Industry." Islamic Banking and Finance Review, Volume 3 (2016): 29-49.

Hakim, Atang Abd. Model of Sharia Compliance on Tourism Industry Development in Indonesia. Bandung, Universitas Islam Negeri Sunan Gunung Djati, 2017.

Langkawi. Qardhawi, M. Y. Halal dan Haram dalam Islam. Jakarta: PT. Bina Ilmu, 1993.

Lembaga Pengkajian Pangan, Obat-Obatan dan Kosmetika. General Guidelines of Halal Assurance System. Bogor: LPPOM Majelis Ulama Indonesia, 2008. 
Ahyakudin, Suja'i, M. Abduh, Sistem Perancangan, Pelaksanaan dan Pengawasan Industri... | 113

Manzouri, M., Ab-Rahman, M. N., Zain, C. R., \& Jamsari, E. A. (2014). Increasing Production and Eliminating Waste through Lean Tools and Techniques for Halal Food Companies. Sustainability, ISSN 2071-1050.

Nasution, Ade Iskandar. "Pendekatan Maqashid Syari'ah dalam Praktik Pembiayaandi Koperasi Peternak Sapi Bandung Utara (KPSBU)." Jurnal As-Syari'ah Vol. 21 No. 1 (Juni 2019): 34-35.

Quraish Shihab. Tafsir al-Misbah: Pesan, Kesan dan Keserasian al-Qur'an (Vol. 3). Jakarta : Lentara Hati, 2005.

Ridwan, Ahmad Hasan, dkk. "Penelitian Terapan dan Pengembangan Global: The Halal Concept and its Implication upon Green Industry in Halal Implementing Countries (Indonesia, Malaysia and Singapore)". Bandung, Universitas Islam Negeri Sunan Gunung Djati, Bandung, 2017.

Samori, Z., Salleh, N. Z., \& Khalid, M. M. "Current Trends on Halal Tourism: Cases on Selected Asian Countries." Tourism Management Perspectives 19 (2016): 131-136.

Soerjono Soekanto. Pengantar Penelitian Hukum, Jakarta: UI Press, 1986..

Undang-undang Nomor 33 Tahun 2014 Tentang Sertifikasi Jaminan Halal.

Winarno Surakhmad. Pengantar penelitian Ilmiah : Dasar, Metode dan Teknik. Bandung: Tarsito, 1989. 
114 | Asy-Syari'ah Vol. 22 No.1, Juni 2020 
Asy-Syari'ah (P-ISSN: 2086-9029 E-ISSN: 2654-5675) is a periodical scientific journal that publishes various results of studies and research, literature review, and other scientific works whose scope covers the field of Islamic law/sharia, law and society in monodisciplinary, interdisciplinary, and multidisciplinary manners. The journal aims to expand and create innovative concepts, theories, paradigms, perspectives and methodologies in the above said scope. The Journal is published twice a year (june and december) by Faculty of Shariah and Law, Sunan Gunung Djati State Islamic University Bandung in collaboration with Asosiasi Sarjana Syariah Indonesia (ASSYI).

\section{EDITORIAL OFFICE:}

Fakultas Syariah dan Hukum UIN Sunan Gunung Djati Bandung J1. Raya A.H. Nasution No. 105 Cibiru Kota Bandung, 40614

Tlp/Fax: +022-7802278 Faks. 022-7802278

Website http://journal.uinsgd.ac.id/index.php/asy-syariah/index

E-mail: Jurnalasy-syariah@uinsgd.ac.id 